\title{
Management Strategies of Carrefour and Ito-Yokado in China: A Comparative Study
}

\author{
Zoe, Zhu Yi \\ University of Hong Kong
}

This research aims to provide an overview of management strategies of French hypermarket Carrefour and Japanese general merchandise store Ito-Yokado in China. In recent years, the Chinese economy has shown profound changes. With numerous foreign enterprises entering the retail market, the competition is especially keen among them. To capture greater market share, Carrefour and Ito-Yokado adapted their management strategies for China. On the one hand, Carrefour entered many cities thanks to their good relationship with local governments, and opened a number of stores. On the other hand, Ito-Yokado, which stands firmly by its dominant strategy, has opened stores in only two cities, and the number of new stores opened is not increasing as fast as Carrefour. The human resource strategies of Carrefour and Ito-Yokado are different; while the former gives personnel authority to the local level, emphasizes intensive training and promotes more Chinese employees to store manager's position, the latter leaves the personnel authority to headquarters, educates employees through daily conferences, and has a slower rate of promotion than the former. The paper concludes that one reason that ItoYokado localizes less human resource management than Carrefour may be due to its corporate culture and Japanese company's behavioral norms. The paper also points out some future research themes.

\section{INTRODUCTION}

In the years since the institution of China's 1978 open-door policy, the Chinese economy has changed profoundly because of several factors. Entry into the WTO in 2001 and changing economic policies have encouraged many foreign companies to expand their markets into China. This paper will focus on the retail industry, in which competition has become very keen in recent years. It was originally necessary for foreign retail companies to find Chinese partners to open stores. However, after the passing of a law in December 2004, foreign retailers can now set up stores in any region. Moreover, they do not have to meet prohibitive asset and sales requirements. Since then, the number of foreign retail companies in China has increased. In 2007, gross sales of the top 100 chain stores in China have passed the one billion RMB mark.

How do foreign retailers practice their management strategy in order to adapt to the changes of China's economy and gain market clout? This paper examines Carrefour, the French 
hypermarket, and the Japanese general merchandise store (GMS) Ito-Yokado (イトーヨーカ堂) as examples to investigate this research question. A hypermarket is "a supermarket with a sales area larger than 2,500 square meters. Products sold in hypermarkets include food, garden items, stationery and books, compact discs, household appliances, toys, camping, sports and home items, clothing, and footwear." (Lira, Rivero, and Vergara, 2007, p.239). General Merchandise Store is a supermarket with a sales area larger than 3000 square meters. Products are domestic supplies, and food and clothing that make up more than $10 \%$ and less than $70 \%$ respectively. The reason this paper focuses on Carrefour is not merely because of its high prestige in the world and its high total sales in China, but also because the company paid much more attention to the Chinese market than other Western counterparts. According to statistics from 2009, Carrefour was ranked top ten in the Chinese retail market, and it has had a huge impact on the Chinese retail industry (CCFA, 2010). The company introduced the hypermarket (大卖场) to the country and opened a number of stores in China. By 2006, there were 1,833 French operated companies in China including Auchan, a French large-scale retailer. However, when the boycott of French products began in April 2008, Carrefour was received great attention of the Chinese media, and a number of Chinese went to the store and protested. The boycott originated from an incident during the Beijing Olympic 2008 torch relay held in Paris ("Karuhu-ru", 2008). Several campaigners for Tibetan independence tried to grab the torch from the disabled female torch bearer, Jin Jing. After hearing the news, many Chinese people began to boycott French goods and Carrefour. It is notable that the company is becoming a part of Chinese people's lives instead of being merely a foreign retailer. Ito-Yokado on the other hand, did not rank as high as Carrefour; however, its unit-store sales are the highest among all retailers thanks to its dominant strategy. According to Seven \& i's official corporate outline 2010, dominance strategy has certain advantages: increasing visibility by customers, making effective production sites, efficient promotion, building effective logistical systems, increasing efficiency advice to affiliated stores, and discouraging competitors from launching into the market (p.14). The company has a reputation for a high quality of service compared to other retailers, including the Japanese retailer JUSCO. Carrefour and Ito-Yokado both have had success in the Chinese retail market with different management strategies. How did they make this happen? This paper will look at their management strategy from two perspectives: store launch strategy and human resource strategy. Store launch strategy is the clearest way to observe the company's overall strategy. The speeds of opening stores, localization of products and the relationship between local governments are related to a company's corporate culture, and these can show us how important the market is to the company. Moreover, it also relates to human resource strategy. In 2008, the competition among retail enterprises shifted from competition over speed of opening stores and their locations to competition for business and human resource management. Since a number of foreign retailers have been in the Chinese retailer market for several years or as long as a decade, some of them have already gained wider recognition. The current challenge for them is not merely opening new stores but also educating and keeping good talent. It is necessary to investigate their store launch strategy and human resource management so as to understand more about their management strategies.

The paper will firstly discuss how Chinese retail changed for various reasons and how this affected the market penetration of foreign retail companies. In the second section, the paper will introduce the corporate history of Carrefour and Ito-Yokado and describe their management principles. Thirdly, the paper will investigate the two companies' store launch strategies and 
human resource (HR) strategies in China. In the final section, the paper will summarize the arguments presented and make several suggestions.

\section{LITERATURE REVIEW}

Among various kinds of strategies that a company practices when they decide to enter an overseas market, market entry strategy and HR strategy play an important role in determining their success. The early literature on market entry strategy fails to fully explain the success or failure of a foreign company in terms of the background of the country's economy, its policy and the relationship with local government. Although there are many works that have been done on HR strategy, few of them analyze the reasons for insufficient localization by the company, and they tend to focus more on localization's advantages than its negative effects. Management practice by Carrefour in China has been studied by many scholars and journalists; however, most of them only look at localization's bright side, and ignore its hidden problems. Moreover, few of them investigate the relationship between its management principle and its practices. Work on Ito-Yokado China is mainly based on interviews and observation from the outside; it is not deep enough to understand the company's management practice in China.

Foreign market entry strategy has mainly been studied from two perspectives; one is market selection and the other is market entry mode. According to Erramilli (1991), there are several important aspects for a company to consider when entering a foreign market, which are market size and market growth, competition, servicing costs, and the host country's social, political and economic environment (p.480). He chooses over a hundred United States-based service firms and finds the more experience a company has in market entry, the more it will tend to select unfamiliar markets (Erramilli, 1991, p. 494). However, he conducts the research only by questionnaire, which includes various kinds of industries, and it ignores each company's uniqueness. Toba (2003) analyzes the overseas market entry strategy of Carrefour in terms of the development in their national market, the background of each entry and its process, and finds out that the company has a flexible entry strategy, adapting the entry mode to every local market. Yahagi (2007) analyzes the management strategies of a Japanese retailer, AEON, in terms of store launch strategy, entry mode and the speed of opening new stores in China. He concludes that the company mainly practices dominant strategy and points out the company opened stores relatively slowly because of its lack of internationalization strategy and insufficient organization to achieve the goal. However, both of them ignore the relationship between local government of the country entered and the company, which might be the key to refining its strategy. There is also an argument that Carrefour's success in Taiwan is because the company rented land instead of buying it, which was its first attempt to do so in an overseas market (Shou, 2003). From this point of view, we could consider whether Carrefour's success in China is also because of its unique strategy for adapting to the local situation.

HR strategy has a close connection with market entry strategy, which means that if a company opens a number of stores in a relatively short time, it is necessary for them to gain and train talent in a short period compared to other companies in which the process of opening stores is slower. Moreover, since human capital plays a significant role in a company, they needed to be managed with a long-term strategy (Suzuki 2007, p.14). The study of HRM mainly focuses on the multi-national company's point of view which is known as international human resource management, IHRM. Works done on IHRM tend to focus on the relationship between parentnational headquarters and subsidiary, and the localization of HRM in overseas market. Western 
companies are compared with Western competitors or Asian companies, which tend to be Japanese companies. Scholars usually find that Japanese companies tend to send many expatriates to the top management class in subsidiaries, suggesting they are more ethnocentric than their Western competitors (Kopp, 1994 and Tung, 1982). There is also an argument that with the increase of local employees with high educational background, there will be more Japanese expatriates since the level of product, technology and service will be higher in the subsidiaries and they needs more parent-nationals to transfer that knowledge (Shiraki 2005, pp. 92-93). Those publications reached their conclusion mainly by looking at statistics and by largescale questionnaires, ignoring the characteristics of each company and its markets. Some scholars argue that Japanese MNCs are advancing their localization in overseas markets. Beamish and Inkpen (1998) find that Japanese companies reduce the number of expatriates because of the limited supply of available position and the recognition of the significance of transferring authority to local management. This is a reliable and recent trend of Japanese companies; however, they fail to explain the process of the recognition, which might be significant for understanding the company's strategies.

Along with China's growth in economy power, there have also been more and more studies on the HRM of foreign companies in the Chinese market in recent years. Works on HRM of Japanese companies focus more on manufacturers than other industries, such as automobile companies, general trade companies, electronics firms, etc. (Seki and Han 2003, Huruta 2004 and Legewie 2000). Most of them criticize the lack of localization of HRM by Japanese companies, which contribute to their failure in the Chinese market. Scholars who have investigated management practice of Japanese retailers in China have come to almost the same conclusion as the former (Yahagi 2007 and $\mathrm{Hu}$ 2003). Although they reached the similar conclusion that there is a lack of localization of HRM in Japanese companies, they did not fully explain what determines their HRM strategy.

Among various types of foreign companies in China, research on Carrefour and Ito-Yokado has concentrated on different aspects, the former as the second-largest retailer which advances its localization in China; the latter as the retailer with the highest unit-store sales in the Chinese market for several years.

The study of Carrefour's overseas management practice can be divided into two parts, which are the Western market and the Asian market. In the Western market, Rugman and Girod (2003) point out that since the percentage of total sales by Carrefour in the non-Western market is much lower than in the Western market, therefore, the company should be analyzed as a regional company. Although this is true, we should not ignore the company's expectations in other markets. Bianchi and Ostale (2006) investigate the failure of Carrefour and other large-scale TNCs in Chile, and they conclude that they failed because they did not adapt their retail practices and retail format to the local context. However, they did not fully explain why those companies failed to localize in these markets. Besides Chile, Carrefour also failed in Japan and South Korea. Aoyama (2007) compares the management practices of Carrefour and Wal-Mart in Japan and concludes that their over-emphasis on low prices and underestimation of the effect of localization caused their failure. According to Coe and Wrigley (2007), after the comparison made between Carrefour and Tesco in South Korea, the former failed to succeed because of the lack of good partnership with local companies. However, a problem with those studies is that they oversimplified the issues contributing to the failures.

Although Carrefour had failed in certain other markets, it had success in China. It has mainly been studied in terms of its flexible management strategy. According to Ko (2003), one of the 
reasons that Carrefour succeeded in China was its flexible strategy to open stores across the country by getting permission from local government instead of central government. However, Ko fails to investigate how they could achieve that, which may relate to localization of HRM. Kanazaki, Yamamoto and Shimizu (2006) argue that in China Carrefour flexibly utilizes the experience of their employees, who had experience all over the world, and who play a role of transformation of knowledge. They also emphasize that Carrefour gives enough personnel authority to the local level. However, they reached this conclusion only by conducting a few interviews with French employees instead of local employees.

In comparison to the literature on Carrefour China, fewer studies have been done on ItoYokado China. The company's management practice in the Chinese market was mainly studied in terms of the control of products' quality, adapting to the need of local customers and the high quality of service (Su 2000, Wei 2004 and Zhao 2010). Most of them agree with the effectiveness of practicing the management of products in the company, such as "Tanpin Kanri ( 単品管理)", which was made to avoid lack of stock, discount and abolition of products. The store changes the floor layout or the number of new arrived products according to the weather. The high quality of service made Chengdu people feel like "emperors" (Zhao, 2010). It is worth mentioning that Ito-Yokado Chengdu tends to be paid more attention than the one in Beijing since Ito-Yokado's Chengdu stores have the highest average total sales in China. According to statistics by CCFA, average total sales of each store in Chengdu are 117,126 RMB and ItoYokado Chengdu is ranked top in terms of each store's sales. Those works have carried out little fundamental investigation into the issue and have over simplified Ito-Yokado's success. There are also some other studies which compare Ito-Yokado to Western competitors in terms of entry strategy and HRM (Hu, 2003 and Ko, 2003). However, they fail to explain why there is a difference between them. Besides those publications, there is also a former executive in the company who joined the planning for entering into the Chinese market and describes its process very thoroughly, which is valuable information (Henmi, 2008).

This paper will first describe the change of the Chinese retail market and its current situation for understanding Carrefour and Ito-Yokado's foreign market strategy. Then the paper will introduce Carrefour and Ito-Yokado's historical development and management principles, which play an important role in their management practices. The paper will investigate the market entry strategy and HR strategy by these two retailers respectively in terms of relationship with the government and localization. Finally, it will compare the two companies' market entry strategy and HR strategy, and propose several problems for further research.

\section{METHODOLOGY}

Human capital plays a significant role since it has the power to decide a company's management strategy. In order to understand the issue of market entry strategy and HR strategy more deeply, it is necessary to conduct interviews both with employees who work at the store and those who work at headquarters. Interviews reveal more about the process of store operation, the relationship among local employees and the relationship between Japanese expatriates and local employees. Moreover, it develops a deeper rapport with the people in the company which may result in them opening up more to the author, allowing the author to see and understand more than they might have as an outsider simply observing the company. It is insufficient to merely interview employees in one city, since each of them has a different retail trade area and customers. For Carrefour, I selected three cities located in the north and the south of China, 
which have different consumption habits. For Ito-Yokado, the author was only able to contact employees in Beijing and in Japan (see Table 1).

TABLE 1

INTERVIEW SCHEDULE FROM 2007 TO 2008 IN CHINA AND JAPAN

\begin{tabular}{|c|c|c|c|c|c|c|c|c|c|}
\hline Year & Date & City & Company & Interviewee & Nationality & Sex & Age & Department & Position \\
\hline \multirow{3}{*}{2007} & $8 / 28$ & Changsha & Carrefour & $\mathrm{A}$ & China & $\mathrm{M}$ & $40 \mathrm{~s}$ & Customer Service & Department Manager \\
\hline & $9 / 4$ & Shenzhen & Carrefour & $\mathrm{B}$ & China & $\mathrm{M}$ & $30 \mathrm{~s}$ & Security & Department Manager \\
\hline & $9 / 10$ & Dalian & Carrefour & $\mathrm{C}$ & China & $\mathrm{F}$ & $20 \mathrm{~s}$ & Consumer Goods & Former Assistant Division Chief \\
\hline \multirow{10}{*}{2008} & $8 / 8$ & Tokyo & Ito-Yokado & $\mathrm{D}$ & Japan & $\mathrm{M}$ & $60 \mathrm{~s}$ & Customer Service & Former Director and Department Manager \\
\hline & $9 / 2$ & Beijing & Ito-Yokado & $E$ & China & $\mathrm{M}$ & $40 \mathrm{~s}$ & Textile & Former Director \\
\hline & $9 / 2$ & Beijing & Ito-Yokado & $\mathrm{F}$ & China & $\mathrm{F}$ & $40 \mathrm{~s}$ & Human Resource & Former Division Chief \\
\hline & \begin{tabular}{|l|}
$9 / 4$ \\
\end{tabular} & Changsha & Carrefour & $\mathrm{G}$ & China & $\mathrm{M}$ & $40 \mathrm{~s}$ & Customer Service & Department Manager \\
\hline & $9 / 4$ & Changsha & Carrefour & $\mathrm{H}$ & China & $\mathrm{F}$ & $30 \mathrm{~s}$ & Human Resource & Department Chief \\
\hline & $9 / 10$ & Beijing & Ito-Yokado & $\mathrm{I}$ & China & $\mathrm{F}$ & $30 \mathrm{~s}$ & 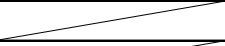 & Secretary of Store Manager \\
\hline & $9 / 10$ & Beijing & Ito-Yokado & $\mathrm{J}$ & China & $\mathrm{F}$ & $40 \mathrm{~s}$ & 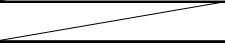 & Store Manager \\
\hline & $9 / 10$ & Beijing & Ito-Yokado & $\mathrm{K}$ & China & $\mathrm{F}$ & $40 \mathrm{~s}$ & Human Resource & Department Chief \\
\hline & $9 / 12$ & Dalian & Carrefour & $\mathrm{L}$ & China & $\mathrm{M}$ & $30 \mathrm{~s}$ & Fresh & Former Assistant Division Chief \\
\hline & $9 / 16$ & Beijing & Ito-Yokado & $\mathrm{M}$ & China & $\mathrm{F}$ & $40 \mathrm{~s}$ & Human Resource & Department Chief \\
\hline
\end{tabular}

In the 2007 interviews, I mainly asked about each store's basic information, its staffing, training and evaluating methods. Most of the interviewees were executives from different departments. The following year, I was able to interview people both from Carrefour and ItoYokado Beijing. The majority of interviewees were in their thirties or forties, and most of them were managers. It is necessary to mention that most of the interviewees from Ito-Yokado worked in the human resources department, and some of them had already worked for more than ten years, which was not the case at Carrefour.

\section{REFORM AND OPENING-UP IN THE CHINESE RETAIL INDUSTRY}

China shifted from a planned economy system to a market economy due to reforms in 1978 . After the reform and opening-up, retail regulations mainly revolve around the concept of the socialist market economy, which has helped develop the Chinese retail market. The development of Chinese retail regulations can be divided into four phases. From 1949 to 1978, Chinese retail merely played the role of distributor, distributing goods in accordance with the state plan. Factories and stores were all owned and operated by the state. Although the intensively planned economy had a positive effect to some extent, it also caused the uneven distribution of productive forces. From 1978 to 1991, the retail market in China was in the starting stage. In this phase, individual enterprises were starting to occupy the market and replace state-run companies. In 1979, the Chinese government divided companies with collective ownership from nationalized companies. There were three types of company for foreign companies that wanted to enter into the Chinese market: Sino-foreign joint venture, Sino-foreign cooperative enterprise and single proprietorship. However, before July, 1992, no foreign company was allowed to enter the Chinese retail market in principle. The so-called number 82 document was enacted in July, 1992, which allowed one or two foreign retailers to enter into six cities and five special economic zones. The six cities were Beijing, Shanghai, Tianjin, Guangzhou, Dalian and Qingdao, and the five special economic zones Shenzhen, Zhuhai, Shantou, Xiamen, and Hainan. However, single proprietorship was not allowed at that time. In August, 1997, the central government 
promulgated a notice which required local government to clean-up and rectify (整理整顿) listed foreign retailers that they had already approved to enter their markets. Clean-up and rectify means that the government investigates foreign retailers and if they are found to be breaking the law, the government will deal with the problem. At the same time, the central government increased the range of locations in which foreign retailers were allowed to open new stores. A notice that was enacted in July clarified the allowed operating period of forty-two foreign retailers, and there were 199 retailers that needed to be cleaned-up and rectified. However, there were still many foreign retailers operating illegally in China, numbering 251 by 2001 according to a notice from central government enacted in August 2001. Carrefour was one of them, and the government required the company's subsidiary in Chengdu to leave the Chinese market. After China entered the World Trade Organization, the retail regulation gradually relaxed so that more foreign retailers could enter into the market, which made competition severe. In 2003, the Chinese government said that it would promulgate a provisional measure that would divide foreign retailers into three categories (A to C) so as to rule and manage them. Companies ranked A are those which have never broken rules; B-ranked companies have broken rules before but corrected afterwards; C-ranked companies still break rules. Companies ranked C would not have permission to enter into new areas of business or open new stores. Carrefour would probably have been ranked $\mathrm{C}$ at that time. However, in February 2004, the government decided not to promulgate the measure since most of the $\mathrm{B}$ ranked and $\mathrm{C}$ ranked companies promised to observe regulations and obey laws. Another provisional measure was enacted by the Chinese government on $16^{\text {th }}$ April 2004, which greatly relaxed the limitation of the scope of business and the type of company. It allowed foreign retailers to do business in any place and it also reduced the capital of companies. Although the measure still leaves some problems to be resolved, it can be seen that the Chinese retail market is moving towards universal opening for foreign retailers.

The retail industry's role as a mere distributor underwent great changes after reform and opening-up. From 1978 to 1991, Chinese retail mainly consisted of large-scale department stores. From 1992, and especially from 1996, there were various types of retailer in the market. According to the Commerce Department of the Chinese government, in 2004 there were seventeen categories of business, which were divided into businesses with stores and those without stores. In recent years, retailers with domestic-investment have dominated the market, most of which are private companies. According to the list of "Chinese chain stores top 100" in 2009 published by the China Chain Store \& Franchise Association, local electrical appliance companies dominated the top three. Some companies increased by $28 \%$ and $34 \%$ in terms of total sales and the number of stores compared to the previous year. Among the top 10, seven were electrical appliance companies and others were department stores or supermarkets, including foreign retailers that have had more presence recently. Foreign retailers are also starting to open new stores in medium-sized or small cities. For example, the speed of opening new stores in those cities by Wal-Mart had increased by $67 \%$ in 2009 . Carrefour also had the same strategy, and seven out of their twenty new stores were opened in medium or small cities. Since the Chinese retail market has opened to outsiders, the competition among retailers has become so fierce that some companies have begun an M\&A strategy in order to expand their business, which means that a few large companies have come to dominate the retail market. Foreign retailers have also merged with and acquired Chinese and Taiwanese retailers in recent years. Wal-Mart acquired the Chinese retailer Trust-Mart in 2006. Tesco bought a 90\% share of Hymall in 2007. 
According to the Teikoku databank, there are 10,778 Japanese companies operating in the Chinese market and $42.4 \%$ of them are manufacturers (Teikoku Databank, 2004). From the size of the company, small-and-medium-sized enterprises, SME, where the number of employees is from ten to fifty, has reached $32.9 \%$. From 1985 to 1996 , Japanese small and medium sized textile companies entered into the Chinese market, and from 1997, larger scale electronic firms, manufactures and retailers gradually increased. Japanese companies tended to see the Chinese market merely as a manufacturing base in the beginning; however, because of market saturation in Japan, weaker domestic demand and the growth of Chinese market, they now tend to have greater expectations from the market and have increased investment (Masuyama, 2004). A variety of industries began to operate their business after China joined the WTO. Since the opening of the Chinese market to foreign companies, the competition is fierce among many fields of businesses. A statistic targeted to Japanese SMEs shows that they plan to open more stores or factories inland instead of in coastal cities (Organization for Small \& Medium Enterprises and Regional Innovation, 2010, p.145). Moreover, they place emphasis on the lack of human capital and the increase of salary as main problems that need to be solved in the near future. The retail market has also opened up and a number of foreign companies opened stores in China. By the end of 2010, there were five Japanese large-scale retailers operating in China; Seven \& I holdings (including Ito-Yokado), AEON, ISETAN, Uniqlo and Heiwado. Although Heiwado only does business in Changsha, Hunan province, all the others have stores in more than two cities.

\section{CORPORATE HISTORY AND MANAGEMENT PRINCIPLES OF CARREFOUR AND ITO-YOKADO}

\section{Carrefour}

Carrefour was established in France in 1959 by Marcel Fournier, Jacques Defforey and his brother, Denis Defforey. The group first introduced the hypermarket to the world in 1963. Carrefour expanded its influence in France. Because of the market saturation inside the country and the law regulating the group opening new stores, the group started to increase the pace of mergers and acquisitions (M\&A), diversify its business, entering into areas such as credit cards and insurance, and entered into overseas markets at the same time. The group opened its first overseas store in Belgium in 1969 and entered into the Brazilian market in 1975. Carrefour opened its first Asian store in Taiwan in 1989. Besides hypermarkets, the group operated harddiscount stores and supermarkets around the world. A hard-discount store is "a self-service store, smaller than a supermarket, with a limited set of products and simple presentation, with low prices and mostly non-branded products." (Gutman, 2002, p. 410) After the acquisition of Promodès in 1999, which had a variety of stores, such as hypermarket (Continent, closed in 2000), supermarket (Champion), hard discount (Dia), convenience store (Shopi, Codec, etc.), cash and carry (Promocash and Puntocash), the group became the second largest retailer in the world.

Carrefour clarifies its management principles in terms of "Our Missions", "Our Values" and "Our Policies" (Shiraki 2006, p.23). Top priority in "Our Mission" is to rank among the top three; otherwise, it will leave the market. Authorizing as much power as possible to the local level plays a significant role in "Our Values" (Carrefour Group 2006, p.6). In "Our Policies", the company emphasizes the importance of hiring more executives from outside and of holding executive conferences regularly for sharing their experiences. 


\section{Ito-Yokado}

The uncle of Masatoshi Ito, honorary chairman of Ito-Yokado founded the procurer of the company “Yokado Yohinten (洋華堂洋品店)” in 1920. The family moved to another place since the company was bombed out during the Second World War. In 1956, Masatoshi took over the operation of the company and established "Yokado (洋華堂)" in April, 1958. During the sixties, department stores had a lead in Japanese retail industry. Besides Ito-Yokado, many GMS, Daiei, Seiyu, Jusco and Uny were established around that time. In 1973, the total sales of Daiei surpassed those of Mitsukoshi, a department store. Ito-Yokado became number one in 1980, and stands firm with a steady business model that has aspired to high revenue and high efficiency from the beginning.

Because of the law that regulated the opening of new GMS stores, market saturation and the bursting of the bubble, some GMS went bankrupt, such as Yaohan, Nagasakiya, etc. Aside from these circumstances, since Ito-Yokado could not respond to the rapid change of the market, the company needed to change the management plan so that the restructuring work started. Top executives did not overlook the problems faced by the company. Masatoshi inspected Western retailers overseas, and decided upon the regular chain strategy, which means headquarters has the authority to manage stores directly. Several years later, the company's name was changed to Ito-Yokado. The company started to enter the overseas market in China in 1996. The company did not enter into any overseas market since then. The company's sales lost its lead to AEON in 2003 and 2004, and the earning capacity of its affiliate company 7-eleven Japan surpassed its parent company, Ito-Yokado. A new company Seven \& i Holdings Co., Ltd. was established in 2005 and Ito-Yokado became its affiliate company. According to the official data provided at the end of 2009, Seven \& i Holdings Co., Ltd. is now the largest retailer in Japan and fourteenth in the world.

On the official website of Ito-Yokado, the company described its motto (社是) clearly as below.

We would like to be an honest company, which customers trust.

We would like to be an honest company, which business partners, stake holders, communities trust.

We would like to be an honest company, which employees trust.

Ito-Yokado placed an emphasis on "honest" and "trust". It seems that the company still stands for the founder of Ito-Yokado, Masatoshi Ito's beliefs, which were "follow the rules" and "hold on to the company's core business". According to Henmi (2008), the company is well known for their work restructuring (業務改革) which began from eighties and had great positive influence on the company. It is actually a restatement and development of the basic requirements towards employees, and it consists of three elements: eliminating slow sellers, hypothesis and verification, and giving authority to the local level. “Tanpin Kanri (単品管理)" is one of the important subjects of the restructure. The company gives authority to part-time employees to order products for job efficiency (Henmi, 2008). 


\section{STORE LAUNCH STRATEGY BY CARRFEOUR AND ITO-YOKADO IN CHINA}

\section{Carrefour}

When a company expands its business into an overseas market, it usually has two factors: one is a "pull" factor; the other is a "push" factor (Toba, 2003, p.64). There are two push factors that prompted Carrefour to enter into overseas markets. One factor is market saturation, which was caused by M\&A by national large corporations in France. For instance, in 2000, the ten largest corporations dominated more than half of the market share (Toba 2003). Another factor is the restriction of opening new large-scale stores in France. Carrefour only opened fifteen new stores from 1999 to 2007 in consequence of the Royer Law (1973) and the Raffarin Law (1996). The pull factor for Carrefour is due to success in Taiwan and an increased Chinese gross domestic product, and the expansion of the retail industry in China. Firstly, the success of Carrefour in Taiwan was mainly due to two points, one is choosing the right partner, and the other is the localization of HRM. There were French store managers in the beginning, however, local store managers increased in number. Moreover, the company gave them a free hand in deciding products' price and which supplier they use. They are also in charge of recruitment and of negotiating the salary with employees. Many Taiwanese store managers have been transferred to mainland China.

Although Carrefour was ranked seventh among retailers in China in 2010, the company did not have the good start. The company entered into the Chinese market without any official permission; but Makro (Netherland) and Ito-Yokado (Japan) did obtain permission. However, the company opened stores without breaking the law in the beginning. According to Ko (2003), in 1995, in order to open stores in Beijing, the group firstly established a consulting corporation, which was not against the law, with a Chinese company and notionally let the company run their store, Chuangyijia Shangcheng (创益佳商城). However, Carrefour had real management authority to operate the store.

Carrefour speeded up opening new stores from 2004 and it had more than 170 hypermarkets in China by 2011 (see figure 1). The company was banned from opening new stores in China from 2001 to 2002 because of the law which was implemented in August 2001 by central government. After solving the problem with the government, the company has continued opening more stores since then. Besides hypermarkets, the group introduced supermarkets and harddiscount stores. Although Carrefour operated 268 hard-discount stores in China by the end of 2009, the group's supermarket, Champion (冠军超市), left the market in 2005.

Carrefour started opening more stores in suburban areas instead of in big cities due to severe competition. For example, the company opened world's 1000th store in Tongzhou (通州), near Beiijng, which is the first suburban store. Carrefour also started to enter into inland areas and the North East area. The company also localizes products. For example, $60 \%$ of grocery and clothing are procured from local sellers in the first store in Xinjiang. Moreover, half of manufactured food in the store accommodates local people's tastes. Besides cooperating with famous or big manufacturers, Carrefour also procured goods from farmers directly. A manager from Carrefour said that this not only increases farmer's salaries but also allows Carrefour to keep good quality with low price.

Besides the above, many Chinese professors and journalists argue about Carrefour's Chinese name “jia le fu (家乐福)” and almost all of them think it is nice and very localized. It is actually the same as the name used by Taiwan Carrefour, and its slogan means enjoy happy shopping in Carrefour (开心购物家乐福). In recent years, Carrefour started a new slogan which is happy at 
home (福到家). Happy (福) refers to many things, such as fortune, good luck, and it is a very important value of the Chinese people. Home (家) means the home of customers, employees and suppliers. Therefore, happy at home (福到家) means to have shopping in Carrefour. The company also made a new rule that if you buy cheaper products in other retail stores, you could get quintuple refund for the difference. It is worth mentioning that every time Carrefour opened a new store, started new slogan, or other changed its president, the Chinese media always reports this on the internet, and the frequency of this is higher than other foreign retailers. Although there has also been negative news about the company, it might be true that Carrefour is good at attracting not only journalists' attention but also that of local government.

\section{FIGURE 1 \\ STORES IN CARREFOUR CHINA FROM 1995 TO 2010}

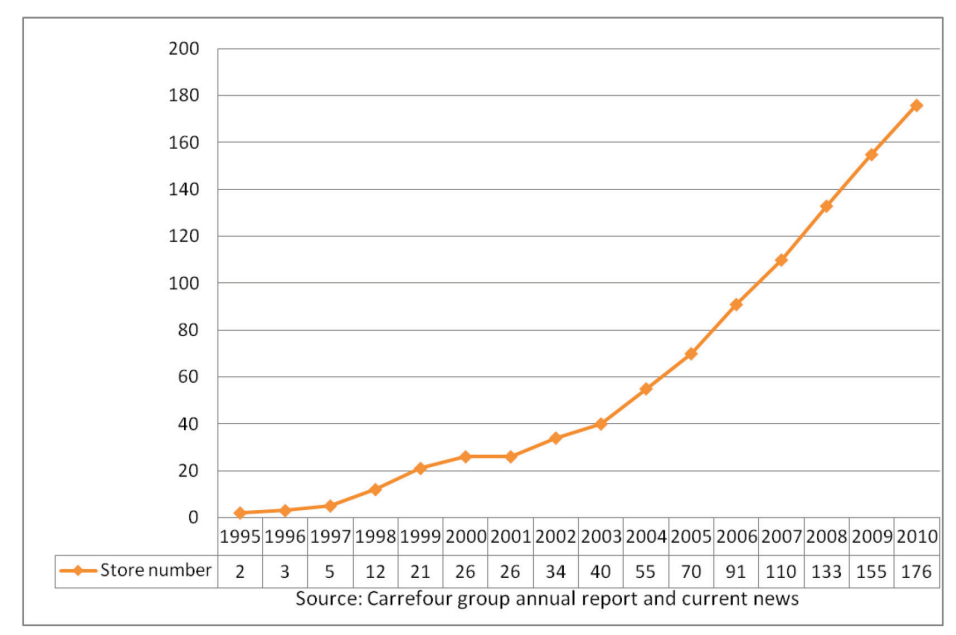

\section{Ito-Yokado}

There are two pull factors for Ito-Yokado; one is the growth of the Chinese economy and the other is the invitation from central government. Firstly, the increase of Gross National Product (GNP), the expansion of the Chinese retail industry and people's high living standard attracted many foreign retailers to enter the Chinese market. Secondly, the Chinese government asked foreign retailers to open stores in China. For Japanese retailers, Ito-Yokado, Daiei and Yaohan were candidates. The central government wanted one of them to help the country to modernize the Chinese retail industry. According to interviewee D, Ito-Yokado was chosen as one of foreign retailers at the end because of its strong sales in Japan and its know-how. The central government thought that although Yaohan had a high loyalty, the company had little know-how. The Chinese government also wanted to attract an American retailer, K-Mart; however, the company rejected the proposal since it had a huge domestic market at that time. Until October 1995, the central government allowed two foreign retailers to enter the market, and each had a Chinese joint partner, including Ito-Yokado. The company partnered with China National Sugar \& Wines Group Corporation (中国糖业酒类集团公司). According to interviewee D, although the founder did not reject the proposal, he was very cautious about the decision since he thought that the company could not afford to fail. However, President Suzuki decided within one week to enter the Chinese market. Ito-Yokado expanded its business into the Chinese market mainly because of two push factors. Firstly, by entering the Chinese market, they wanted to cultivate 
employees' spirit of an international sense of business since it was the first time that the company opened an overseas store, and top executives thought it would help employees to get to know more about international business. Secondly, Ito-Yokado's management team thought that China could support Japanese business as merchandise procurement. Ito-Yokado was the first foreign company which had the right to open a far-reaching chain throughout the country.

Ito-Yokado established a subsidiary in Chengdu, China in 1996. The company chose an inland city because of two reasons; one was the connection with the Japanese trading company Itochu, which is the company's biggest business partner, and the other was the local government's great effort. According to Li (2008), there is a well-known story called the "flying bike story" (p. 40). It says that although the process of opening new company took several months at that time, the mayor of Sichuan province gave an order to complete all documents in one day and it became true. In the next year, the company founded an affiliated company in Beijing. According to the data from the company's official website, Ito-Yokado had nine stores in Beijing and four in Chengdu, total of thirteen stores in China by June 2010. Based on the Chinese retail statistics in 2009, the total sales of Ito-Yokado Chengdu was ranked sixty-two; however, the average of each Ito-Yokado (Chengdu) store's sales was RMB11.7 hundred million, which was the highest among foreign retailers. Ito-Yokado was one of the most popular companies in Chengdu; moreover, it maintained a high growth rate of $20 \%$ each year.

Ito-Yokado opened stores based on their dominant strategy, which makes the company open new stores at a relatively slow speed. Although Ito-Yokado opened new stores at a relatively slow speed, the company accelerated the rate of opening stores in recent years. By 1 June 2010, the company operated 12 stores in China. After opening the first store in 1998, Ito-Yokado opened a second store in Beijing three years later. From 2001 to 2004, the company opened a new store every two years, but from 2005, Ito-Yokado opened its fifth and sixth stores in one year. On the other hand, it seems that Chengdu Ito-Yokado opened new stores at a very slow speed compared to Beijing, which hosted the Olympic games; however, the fourth store is supposed to open in three years, which is faster than the second one, in five years, and the third one, in four years. Thanks to Ito-Yokado's dominant strategy, the total sales of Beijing and Chengdu were increasing. In 1999, sales in both Beijing and Chengdu were almost same; however, because of the speedy expansion in Beijing, the company's total sales were ahead of those of Chengdu.

The company localizes its products. It gets $100 \%$ of clothing and $95 \%$ of fresh food from China (Li, 2008, p. 46). Moreover, the company operated as a department store in China and the good reputation attracted many stores to move in, which is called the shops in the store (店中店) business model. Ito-Yokado had done its best to make the atmosphere in the stores adjust to local resident's preferences and customs so that they introduced some corporate customs. One important custom is that they change shop floor's layout according to the weather. They do not only check the weather one time a day, but every hour and employees can see the weather map the way to the staff room. They also capture the different fashions of people in Beijing and Chengdu. According to interviewee D, people in Beijing like to wear relatively dark colors; however, Chengdu residents tend to wear bright colors, therefore they procure accordingly. The company went to great efforts to satisfy their customers. Unlike Carrefour, Ito-Yokado has little media exposure; interviewee D said that "We want to help modernizing the Chinese retail and introduce the high quality of service, not to promote our self." Mr. Saegusa, the president of Chengdu Ito-Yokado, said to the local newspaper that "We do not want to compete with others; the important thing is to guide and investigate inside the company and challenge our self". 


\section{HUMAN RESOURCE STRATEGY BY CARRFOUR AND ITO-YOKADO}

\section{Carrefour}

Carrefour China was divided into four areas: central-west, east, south and north. Each area's headquarters was located in Shanghai, Chengdu, Guangzhou and Beijing respectively. They had power for purchasing, marketing, finance, and press relations. However, along with the tendency towards centralization in recent years, the organizational structure and their authority might have changed.

Carrefour's stores were composed of the commercial department, which has five departments (Consumer Goods, Fresh Bazaar, Appliance and Textile), and the service department. In each department, there were five levels of position: regular employee, assistant department chief, department chief, department manager and store manager.

\section{Recruitment}

Each store was able to recruit executives without waiting for approval from branch offices. Employees were mainly regular employees with one or two year contracts, with few internships and part-timers. Carrefour recruited employees through the internet or at job fairs in the community or at schools. Internship and part-time employees could be found mostly from job seeking websites. In order to attract more top-level staff, Carrefour tended to hire executive candidates from university job fairs. The company hired regular employees as cashiers directly from job fairs in the community. The qualifications required for Carrefour's regular employees had several common points, which were age from 20 s to 30 s with a relatively "modest" education level, such as junior high school, technical secondary school (中专), and high school to secondary vocational technical school (职业中专). However, the company required applicants for executive candidate positions to have a diploma, which varied from junior college (大专) to university, and English ability. Carrefour emphasized English ability because executives above departmental manager were supposed to share experiences with foreigners at regular conferences as declared in "Our Policies". According to interviewee G, strong English ability had a positive influence on their promotion.

Applicants needed to conduct interviews which had four steps. After applicants sent their resumes to HR, an employee from the department would interview them. The next interview would be held in several days with the department manager. A final interview was conducted with the store manager. Interviewers mainly observed how applicants handled the problems they were presented with, how much they cared about the importance of teamwork, and whether they followed their superiors.

\section{Training}

Carrefour placed emphasis on recruiting more employees from the younger generation (Chen, 2007). Due to the high speed of opening new stores, the company struggled to find sufficient executives. It was not easy since an employee needs a minimum of six years to become a store manager. In order to gain qualified executives, the company strengthened training programs from June 2005 (An, 2006).

This paper focuses on executive training, which is significant for the company. Carrefour had two levels of training centers; one was national and the other regional. The "Carrefour China Institute (CCI)" in Shanghai was the national level training center, which was established in March 2000. It mainly trained store manager candidates and district manager candidates. Other 
candidates took training in the regional training centers, which were located in each city or prefecture. Executive training mainly had three types, which were division manager candidates (Executive Training Program, ETP), department manager candidates (Management Development Program, MDP) and store manager candidates (Carrefour Mandarin Training, CMT). For ETP, Carrefour recruited the majority of candidates from outside, and they were required to have a diploma and English ability. For example, among eleven candidates for Chengdu ETP assessed in April 2004, more than $80 \%$ had a bachelor's degree, and others had a master's degree. Moreover, the company tried to hire more employees who are from the local area. In the Tianjin ETP recruitment during May, 2004, all candidates had graduated from local schools.

Carrefour emphasized the training program for store manager trainees. For instance, CMT increased five times in 2006 compared to 2000 . Moreover, the company promoted sixty more local people to store manager in 2007. In some cities, such as Wuhan and Guangzhou, all store managers or even district managers were Chinese who were their 30's. This shows that Carrefour recruits and promotes local young people. The company recruited more local people and increased their training for accelerating the promotion process in order to have sufficient qualified executives in China. An executive from headquarters of the company declared that it plans to allow Chinese managers to run the business from 2018.

\section{Evaluation}

Employees were mainly evaluated by their attendance and job performance. Job performance was evaluated during the apprenticeship period and at the end of that year. It contained various factors, such as work attitude, accomplishment, teamwork, observance of rules, etc. Employees had a second chance when they failed the first time.

Compensation included basic compensation, reward and allowance. A person in charge in each department had the right to decide the details and amount of the reward. The company strictly banned employees from sharing details of their compensation with other people, and those who disobeyed would suffer punishment. Carrefour's compensation, especially executives, was ranked in the middle class in China. However, according to Bin (2003), assistant division managers only got around RMB 2,000 to RMB 3,500. According to the data collected in 2008, a store manager's monthly compensation was around RMB 50,000 to RMB 60,000, and an assistant store manager got RMB 20,000 a month. Each executive's compensation was quite different and this could be a factor in motivating employees.

\section{Ito-Yokado}

According to the official website of Ito-Yokado Chengdu, the company had headquarters of operation, management, finance, and information system, a total of four headquarters. I will briefly introduce the operation and management headquarters, which have various kinds of departments. In operation headquarters, there are the departments of commerce and sales. Each department had some people to control the store and its products (店舗統括 and 商品統括). Other than those departments, the company also had departments of industrial education, industrial development, internet supermarket, Supervision (SV), distribution, customer service and sales promotion (SP). In management headquarters, there are the departments of development, human resource, general affairs, quality management and foreign affairs. There is also a department which controls management (管理統括).

Ito-Yokado's stores had a commercial department (Clothing, Housing and Food) and a service department until 2007. In the commercial department, positions were classified into five 
levels: regular employee, chief, director, manager, and store manager. In the service department, it was classified into three levels: regular employee, director and manager. In this paper, "executive" means an employee who ranked above department chief in a commercial department or above chief in the service department.

\section{Recruitment}

The person in charge of each department worked together with the department of human resources for recruitment. In Ito-Yokado, only headquarters had the right to hire executive candidates. The company was composed of permanent staff, interns, and part-timers, and they renewed their contracts according to the law. Recruitment will be examined by method and qualification. Firstly, each Ito-Yokado store generally found employees by itself through the Internet or at job fairs. The Internet was also used to recruit interns from universities and colleges and part-time staff. Job fairs were usually held in schools. Ito-Yokado selected interview candidates with expertise through school job fairs. Unlike some European supermarkets, Ito-Yokado did not tend to hold community job fairs, and hired regular employees such as cashiers directly. Secondly, I examined recruitment qualifications both from recruiting advertising on Internet and interviews. It can be seen from recruiting advertising that Ito-Yokado set higher qualification requirements for executives than for regular employees. On the one hand, qualifications for regular employees were with a relatively modest education level. For example, they required the employee's academic background variously to be junior high school, technical secondary school, and high school to secondary vocational technical school. On the other hand, common qualifications for executives included a relatively high education level and job experience. In terms of managerial educational background, although a regular employee with a junior high school education could be promoted to management level, the company tended to hire executive candidates with a bachelor's degree. According to interviewee K, a bachelor or above degree does not guarantee that the holder is absolutely good at the job; however, people who went to higher education institutes have more knowledge than others and they are more capable of understanding business contents and regulations than others. Moreover, Ito-Yokado tended to promote regular employees to executives from the company so that the company only hires from outside when it comes to a pinch. Ito-Yokado did not place too much emphasis on Japanese ability since Japanese managers usually have a full-time translator.

According to interviewee $\mathrm{J}$, Ito-Yokado had four steps for recruitment. First, sending a resume to the department of human resource management, where there is a screening. Second, some Chinese employees from Ito-Yokado will interview candidates and interviews will include the candidate's understanding of the company's corporate culture. Third, there is a paper test, which examines basic knowledge. Finally, managers from Ito-Yokado, which include Japanese staff with translators, interview candidates. The first interview and the second are quite different and in the latter one, interviewers ask candidates more specific questions about the company. Because of the good reputation of the company, many freshmen apply for the executive positions each year, so competition is very fierce. On average only half a percent of the applicants will be recruited.

\section{Training}

Ito-Yokado is well-known for its high quality service in China. According to 2006 statistics, customer satisfaction toward service was ranked the highest (Wang, Li and Lu, 2006). ItoYokado had done its best to make the atmosphere in the stores adjust to local resident's 
references and customs, and had maintained their high-quality service. Therefore, the company put great effort into training. The company organizes training for employees so they can gain more knowledge about the industry, and so as to transmit its corporate culture. Compared to certain Western retailers, Ito-Yokado placed less emphasis on intensive training. According to interviewee $\mathrm{E}$, the company transmitted its corporate culture mainly by daily conference. I shall talk about the training in different positions first and then I will describe the conferences. Before the store opens, for regular employees and executive candidates, the training mainly had two parts; one was taking courses for general knowledge at headquarters and the other was practicing in genba (現場). For the general part, the company taught employees how to dress appropriately, how to bow, facial expressions with customers, and so on. Employees had a printed manual, which was based on that of Ito-Yokado Japan. Other than those manners, employees also studied the company's management principles, corporate culture, code of conduct, contract of employment and welfare that employees could get.

In Ito-Yokado, headquarters organized training for executive candidates. They gained knowledge about the sales floor, regulation of the company and career planning. For those of manager level, common contents of the training were management of the sales floor, application of data, sales plans, human resource management, and company strategies. The training lasted for two to three months, with classes at headquarters and on-the-job training (OJT) in each store. Store manger candidates had the chance to go to Japan for training, which lasted for one week. The company organized this training once a year and Japanese ability was not required. The characteristic of this training was that most candidates were women; for example, among five candidates, four were women in 2008. At the end of the training, participants needed to make a presentation at a conference after they went back to China.

Other than training before the opening of stores, there was also daily training. For example, employees who worked in Xizhimen store (西直門店) watched a tape every Tuesday and Wednesday. The content was different from time to time, for example, they focused on training for security when I did my interview in 2008. Besides training for employees from Ito-Yokado, the company trained employees from other shops every Monday and Tuesday at the Xizhimen store. Besides formal training, once employees enter the company, they received a handbook. It allowed them to gain some knowledge about the company's corporate culture, the way to behave on the shop floor, how to dress properly, how to bow, etc. It was based on Ito-Yokado headquarters' handbook, and employees in the human resource department edited it according to the Chinese situation. The difference between Ito-Yokado and Carrefour's handbook is that the former has more pictures and requirements of the way of talking or of behavior.

The second important way for Ito-Yokado to transmit its corporate culture so as to train employees is to have a meeting or a conference. According to Ito-Yokado's first Chinese store manager interviewee $\mathrm{E}$, the company insists on holding a daily conference every morning and night. As he described, through the daily conference, the company was able to convince employees to believe in their corporate culture, or even "brainwash" them. Moreover, he stressed that sharing information between managers and regular employees and daily conferences were the most effective way to make that happen. Unlike some retailers who limited the meeting time to thirty minutes or cut down the number of meetings, Ito-Yokado still asked managers to regularly schedule a meeting (see Table 2). Ito-Yokado tried to pass on information by holding meetings every week. According to interviewee E, it was hard to say that all of these meetings were useful; however, he believed that it was a process of training and "brainwashing" since 
managers repeated the company's corporate culture when they passed on the information.

\section{TABLE 2}

DAILY CONFERENCE IN ITO-YO-KADO (BEIJING)

\begin{tabular}{|c|c|c|}
\hline \multicolumn{3}{|r|}{ Head quarter } \\
\hline Date & Time & Contents \\
\hline \multirow[t]{2}{*}{ Monday } & Morning & $\begin{array}{l}\text { President, department managers and other executives attend the } \\
\text { coference about company's operation }\end{array}$ \\
\hline & Afternoon & Department superiors have meeting with their subordinates \\
\hline \multirow[b]{2}{*}{ Tuesday } & Morning & Executive meeting \\
\hline & Afternoon & $\begin{array}{l}\text { Store managers, employees in management class from each } \\
\text { department attend a meeting hosted by board of directors }\end{array}$ \\
\hline \multicolumn{3}{|r|}{ Store } \\
\hline Monday & Afternoon & $\begin{array}{l}\text { Executives pass the information from meeting in head quarter to } \\
\text { employees whose lank is upper than department chief }\end{array}$ \\
\hline Wednesday & Morning & Store mangers pass the information to every employee \\
\hline \multicolumn{3}{|c|}{ Source: From interviewee E } \\
\hline
\end{tabular}

Because of the high requirement of the quality of service, some stores did certain kinds of punishment recently. According to the local news paper, in May 2010, a store in Beijing punished two employees to stand up in the passage way to the staff room and bow every time their colleagues passed by for twenty minutes (Beijing Business Today, 26 May, 2010). The store manager decided to punish employees who did not obey the rules - for example long hair that needed to be tied up, failure to stand up straight on the shop floor, leaving their post and chatting with colleagues, using a mobile phone - and he said that it is absolutely not in accordance with the company's requirements. However, according to the news, it had happened in other stores and some employees who have been punished in the same way resigned because they thought it was a deep insult to the personality. Although some professors and customers do not agree with it, executives from Ito-Yokado think that it is just a method to make employees obey the rules. Moreover, one way to train employees to bow and greet is letting them stand in the passageway to do that.

\section{Evaluation}

The evaluation section is divided into three parts: basic evaluation, compensation system, and promotion. Firstly, employees' attendance was recorded by a clock card. They were required to wear uniforms when they punched their time card. According to interviewee F, an employee who came late to the store faced a RMB 30 penalty. Compensation was divided into three parts: basic compensation, reward and allowance. Although the company tried to make an effort to keep good talent, the Chinese tended to move to another company with a higher salary very frequently. For example, once when a Chinese department store called New Century Department store (新世纪百货) was established in same district as Ito-Yokado, 60 employees left ItoYokado for higher pay. It is true that some of them returned to Ito-Yokado after several years because they thought they could learn more from the company; however, compensation always was a problem for Japanese companies to gain good talent compared to Western or even mainland Chinese competitors. Secondly, a performance assessment is done during the 
apprenticeship at the end of the year. It contains various elements, such as work attitude, capability, accomplishment, teamwork, and observance of rules. The apprenticeship performance assessment is very important since it decides whether the candidate will be hired or not. However, even if they fail the assessment, the group will offer them another chance to try. Assessment at the end of that year will be appraised by the person in charge of their department, and then the human resource department will perform a comprehensive evaluation of the assessment.

The promotion system was questioned by some employees. When I was doing interviews in Beijing, many employees said that they were not satisfied with the compensation system since the qualifications required for promotion were not clear enough. Moreover, if a Chinese employee wanted to be promoted to the core part of the company, they need permission from the Japanese top management class, which reduced Chinese employee's motivation or even caused some mainstays of the company to leave. For example, the HR department at headquarters used to have the right to assign executives such as department chief, which was ranked lowest in the management class; however, it required permission of the vice president and president several years later. According to interviewee E, who worked in Ito-Yokado for almost ten years and helped the opening of the first store in Beijing, communication with Japanese employees was a one-way street. Moreover, he pointed out that Japanese managers were still complacent with past success, so it was very hard to implement reforms. However, Ito-Yokado may have some changes. A first Chinese executive joined the board in Chengdu Ito-Yokado and she is the only female. Beijing Ito-Yokado has Chinese executives; however, one of them, who used to be the division head, resigned and moved to a local retailer to be a vice president. Both Ito-Yokado Beijing and Chengdu promoted a number of Chinese executives to store manager. Besides promotion, Chengdu Ito-Yokado had transferred 220 employees from headquarters to stores and vice versa (Wu, 2010).

Many scholars, economists, and journalists criticize Japanese companies for failing to advance localization of HRM in overseas market when compared to Western companies. ItoYokado used to be one of them. Based on interviewee J's information, among 3,000 permanent employees in Ito-Yokado Beijing, there were fifteen Japanese by 2008. Moreover, they held eminent positions in the group, such as chairperson or vice-chairperson of the board and store manager. However, the situation is changing slightly over time. Although half of their store managers in Beijing were Japanese men by 2007, there were six Chinese store managers including two females in nine stores by June, 2010, which means Chinese store mangers constituted more than half of all store managers. Moreover, although some store managers were Japanese, the assistant store managers were all Chinese. We can see that Ito-Yokado is actually trying to advance its localization of HRM.

Ito-Yokado had strict punishment for employees who broke the rules at the shop floor, such as using mobile phones, chatting with colleagues, etc. The company imposed a fine on employees, and required them to stand still near the entrance for staff saying Welcome to the store (欢迎光临) each time when someone passed by. Some employees regarded standing still as an insult and refused to obey.

\section{A COMPARISON BETWEEN CARREFOUR AND ITO-YOKADO}

Ito-Yokado and Carrefour entered into the Chinese market under different circumstances. Firstly, both Carrefour and Ito-Yokado entered into the Chinese market because of its high 
economic growth and the development of the Chinese retail industry. They also have other factors. On the one hand, Carrefour has a long history and has wide experience operating in overseas markets. Their success in Taiwan also prompted the company to enter the Chinese market. Although Carrefour did not have the permission of central government for entering into the Chinese market, the company had good relationship with local government and this allowed the company to open many stores in a relatively short time. This was also based upon one of the company's management principles, which place emphasis on being the top retail store in the market. On the other hand, China is the first and only overseas market that Ito-Yokado was launched in, and the company also has great expectations as a result. Moreover, according to Henmi (2006b), the central government expected Ito-Yokado to introduce advanced technologies and customer service. The company truly wanted to help develop the Chinese retail market instead of just ranking at the top. Secondly, they have different store formats in China. ItoYokado introduced GMS and operated stores in both Beijing and Chengdu. While Carrefour introduced the hypermarket into the Chinese market, the group also operates hard-discount stores. Both retailers localize their products. Thirdly, they launched stores in different regions and their speed in doing so was quite different. Ito-Yokado seemed to grow more slowly since the group only opened stores in two cities in ten years compared to Carrefour which operates hundreds of stores not only in big cities but in suburban areas.

Furthermore, the two retailers operated differently in terms of HR strategy. Firstly, although they hire regular employees and executive candidates through similar methods, their strategy in personnel authority is quite different. Carrefour gave local people enough authority to recruit qualified executives; however, Ito-Yokado restricted this. Secondly, Carrefour tends to place an emphasis on intensive training, and is able to train employees near their stores, such as at a regional training center. Ito-Yokado, on the other hand, prefers to place great value on daily meetings and OJT. Ito-Yokado's headquarters organized the training every time; Carrefour, by contrast divided its training center into two main groups, which are national and regional. Finally, their compensation and speed of promotion is different. Although each company's exact salaries are not clear, high salary is one important element in keeping talent. It seems that Carrefour is doing better than Ito-Yokado. Since Carrefour is opening many more stores than ItoYokado, the former has more places for promotion than the later. However, Ito-Yokado is also advancing its localization of HRM from this point of view. There is also a difference in the proportion of PCNs in each store. There are a number of PCNs in Ito-Yokado; however, in Carrefour, although PCNs accounted for a large fraction of board members in every subsidiary company, there was a low percentage in the store level.

Through a comparison of Ito-Yokado and Carrefour, it is clear that the latter is advancing its localization of HRM more than the former by transferring personnel authority to the local level, and the appointment of more Chinese to store manager positions. The reasons for this could be explained from two points of view. One is from the point of view of the Japanese company's culture, custom or behavioral norms; the other is the company itself. Japanese companies overseas have been criticized for their practice of HRM compared to Western companies, such as low rank of salary, low speed of promotion and not enough local top managers. The situation has slightly changed as is proved by Ito-Yokado. However, the Japanese retailer focuses more on details than their Western counterparts and requires a high quality of service. In order to achieve this, it is not realistic to train and educate employees in a short period. It is necessary to "brainwash" them by daily education. Therefore, they tend to take long time to educate employees even though they recognize that it might lead to a low rate of promotion and other 
results. The other factor is that Ito-Yokado's corporate culture does not place an emphasis on profit, sales or ranking, but on the trust and the contribution to society, which has a great influence on company's management strategies.

\section{CONCLUSION}

This paper described changes in Chinese retail and retail policy, Carrefour and Ito-Yokado's expansion into China and their management strategies. Chinese retail policy has changed and regulation was alleviated to some degree because of the open-door policy, entry into the WTO, and the law that was instituted in 2004. Therefore, the competition among foreign retailers has become severe and every company goes to great effort to gain a dominant market position. Carrefour and Ito-Yokado had different management strategies in China. Carrefour opened many stores in China in order to follows the company's "mission", which places emphasis on high ranking and a dominant position in the market. As a result, the lack of sufficient employees, especially qualified executives, became a serious problem. In order to solve this problem, the company accelerated the localization of HRM. Carrefour gave authority to local people to recruit executive candidates, and trained them by intensive training mostly in local areas, and then promoted as many Chinese employees as they could. Ito-Yokado, on the other hand, because of their concentration on details and on quality of service, tended to educate employees from the very beginning and teach them thoroughly by daily conferences, which employees described a process of "brainwash", and which led to a relatively slow speed of promotion. Although ItoYokado has advanced its localization of HRM in recent years, it does not localize as Carrefour does in terms of transferring personnel authority to the local level and promoting Chinese to executives. The reason why Ito-Yokado localized less HRM than Carrefour could be explained in terms of Japanese company's behavioral norms and customs, and the company's corporate culture, which spent a long time on on-the-job-trainig. It also forced them to strengthen punishment. This is the opposite of Carrefour to some extent, since the company focused more on the company visibility and its status in the Chinese market. By investigating Carrefour and Ito-Yokado, it is relatively clear that their management principles play a significant role in their strategies. It is getting harder for a company which wants to enter into the Chinese market to follow the example of Carrefour since the competition is much more intense and the Chinese people's consumer behavior and preferences are changing nowadays. In order to be a winner in the Chinese market, it is important to have sufficient financial resources and a clear overseas strategy, and to understand what Chinese customers really want nowadays. Although ItoYokado's strategy is taking some time to see fruits, it actually affects an increase in the total sales.

The paper has several limitations and unresolved issues. It is true that companies change very quickly and this paper may not contain up-to-date information. It should be noted that this paper is only an initial attempt to explore the localization of retail companies in the Chinese market, and additional research on the following areas is needed for a better understanding of the issue. First, how do foreign managers actually deal with local employees? What causes problems of communication? Each Japanese executive in Ito-Yokado has a translator, which might be the gap between Japanese bosses and local subordinates. Second, how far should a company practice localization? Almost all employees and store managers in Carrefour are Chinese; however, is this really a good thing? After Carrefour entered into the Chinese market, the company has had many food safety issues. Many customers wonder why this only happens in China but not in France. 
There have been many accidents or fights between employees or security staff and customers. Besides these problems, bribery between employees and suppliers is also a serious issue for Carrefour. It might be because of their delegation of "sufficient" authority to the local level, intensive training and quick speed of promotion. How should the company resolve these problems? Finally, should retailers in China shift their strategy from "low price, cheap quality, bad service" to "middle price, high quality of products and service"? Along with economic growth and increase of people's level of consumption, Chinese people need products with high value and stores whose employees are well trained. Carrefour still does not place much emphasis on the quality of products or service but more on the price. It is important to note that not only foreign retailers but also local companies probably need to shift their management strategies so as to satisfy customers and gain market dominance in this fast-changing global economy.

\section{REFERENCES}

An, J. (2006). Jialefu Peixun: Dianzhang Shi Zheyang Lianchen De. Science and Technology Innovation Herald, 1, 43-44.

Anderson, E., \& Gatignon, H. (1986). Modes of foreign entry: A transaction cost analysis and propositions. Journal of International Business Studies, 17, (3), 1-26.

Aoyama, Y. (2007). Oligopoly and the structural paradox of retail TNCs: an assessment of Carrefour and Wal-Mart in Japan. Journal of Economic Geography, 7, 471-490.

Bartlett, C. A. and Ghoshal, S. (1989). Managing Across Borders: The Transnational Solution, London: Hutchinson.

Beamish, W. P. and Inkpen, C. A. (1998). Japanese firms and the decline of the Japanese expatriate. Journal of world business, 33, (1), 35-50.

Bianchi, C. C., \& Ostale, E. (2006). Lessons learned from unsuccessful internationalization attempts: Example of multinational retailers in Chile. Journal of Business Research, 59, (1), 140147.

Bin, Q. (2003). Jinshen Zhuangtai He Xingwei Fangshi Jueding Fazhan, Shanghai Education, 7, 47-49.

Björkman, I., Budhwar, P., Smale A. \& Sumelius, J. (2008). Human resource management in foreign-owned subsidiaries: China versus India. The International Journal of Human Resource Management, 19, (5), 964-978.

Carl F. F., \& Björkman, I. (2001). The Effect of human resource management practices on MNC subsidiary performance in Russia. Journal of international business studies, 32, (1), 59-75.

CCFA. (2010, April, 9). Top 100 retailers. Retrieved , Jan 21,2011from CCFA official website, http://www.ccfa.org.cn/viewArticle.do?method=viewArticle\&id=ff8080812793a257012793a68a fb0003\&publishcid=402881e91 c59dbcb011 c59e030db0005 
Chen, S. \& Wilson, M. (2003). Standardization and localization of Human Resource Management in Sino-Foreign Joint Venture. Asia Pacific Journal of Management, 20, 397-408.

Chen, G. (2007). Jialefu Neimu, Shenzhen: Haitian.

Coe, N. M., \& Wrigley, N. (2007). Host economy impacts of transnational retail: the research agenda. Journal of Economic Geography, 7, 341-371.

Erramilli, K. M. (1991). The Experience Factor in Foreign Market Entry Behavior of Service Firms. Journal of International Business Studies, 22, (3), 479-501

Gutman, G. E. (2002). Impact of the Rapid Rise of Supermarket on Dairy Products Systems in Argentina. Development Policy Review, 20, (4), 409-427.

Henmi, T. (2006a). Koza Bijinesu No Souzo To Jissen, 52-53.

Henmi, T. (2006b). Saishin No Chugoku Ryutu Jijyo. Shumei Daigaku Gendai Kigyoron, 30-35.

Huruta, A. (2004). Chugokuni Okeru Nikkei Kigyo No Keiei Genchika, Tokyo: Institute of Business Studies, ChukyoUniversity.

Hu, X. (2003). Kokusai Kouri Kigyo No Chugoku Senryaku -Karuhu-ru To Ito-yo-kaodo No Jirei Hikaku. In Yahagi Toshiyuki, (Ed.), Chugoku • Ajia No Kourigyo Kakushin, Tokyo: Nikkei.

Jarillo J. C., \& Martinez I. J. (1990). Different roles for subsidiaries: The case of multinational corporations in Spain. Strategic Management Journal, 11, (7), 501-512.

Johansson, J. K., \& Yip, G. S. (1994). Exploiting globalization potential: US and Japanese strategies. Strategic Management Journal, 15, (8), 579-601.

Kanazaki, M., Yamamoto, T., \& Shimizu, S. (2006). Chugoku Deno Jigyo Tenkai to HRM. In Enatsu, K. (Ed.), Sa-bisu Takokuseki Kigyo No Jinteki Shigenkanri -Karuhu-ru No Kokusai Tenkai Wo Jire Toshite (pp. 47-63). Tokyo: Research Institute of Business Administration, Waseda University.

Karuhu-ru Hubaiundou. (April 20, 2008). Nikkei Marketing Journal, p. A4

Ko, L. (2003). Karuhu-ru No ChugokuTairiku Deno Senryaku Tenkai. Discussion paper from Kobe University Graduate School of Business Administration. Retrieved June 10, 2011, from http://www.b.kobe-u.ac.jp/paper/2003_19.pdf

Kopp, R. (1994). International human resource policies and practices in Japanese, European and United States multinationals. Human Resource Management, 33, (4), 581-599. 
Lane, C. (1998). European companies between globalization and localization: a comparison of internationalization strategies of British and German MNCs. Economy and Society, 27, (4), 462485.

Legewie, J. (2000). Production Strategies of Japanese firms: building up a regional production network. Jochen, Legewie and Hendrik Meyer-Ohle (eds.) Corporate strategies for Southeast Asia after the crisis, Basingstoke: Palgrave, 74-99.

Li, T. (2008). Ito-yokado No Chugoku Shinshutsu -Jisharyu He No Shunen Ni Motoduku Genchika. Keizairiron, Keizai riron, 345, 29-58.

Lira, L., Rivero, R., \& Vergara, R. (2007). Entry and Prices: Evidence from the Supermarket Sector. Review of Industrial Organization, 31, (4), 237-260.

Lu, Y., \& Ingmar, B. (2001). HRM practice in China-Western joint ventures: MNC standardization versus localization. The international journal of human resource management, 8 , (5), 614-628.

Masuyama, S. (2004). Chugoku Keizai No Taitou, Higashi Ajia Chiiki Tougou no Shinten To Naigai Kigyou No Chugoku Senryaku. Chitekishisansouzou, 5: 4-27.

Organization for Small \& Medium Enterprises and Regional Innovation, JAPAN. (2010, March). Report on the practices of SME in overseas market. Retrieved Feb 5, 2011 from http://www.smrj.go.jp/keiei/dbps_data/_material_/b_0_keiei/kokusai/pdf/06H21Report_Chapter 4.pdf

Pudelko, M., \& Harzing, A. (2007). Country-of-origin, localization, or dominance effect? An empirical investigation of HRM practices in foreign subsidiaries. Human Resource Management, $46,535-559$.

Rugman, A.M., \& Girod, S. (2003). Retail multinationals and globalization: the evidence is regional. European Management Review, 21, (1), 24-37.

Seki, M., \& Han, K. (2003). Genchika Suru Chugoku Shinshutsu Kigyo, Tokyo: Shinhyoron.

Seven \& i. (2010). Corporate outline 2010. Retrieved 3 March, 2011 from http://www.7andi.com/en/ir/pdf/corporate/2010_all.pdf.

Shiraki, M. (2005). Chaina • Shihuto No Jinteki Shigen Kanri, Tokyo: Hakuto-Shobo.

Shiraki, M. (2006). Karuhu-ru No Pari Honsha: Kokusai Tenkai To HRM. In K. Enatsu (Ed.), Sa-bisu TakokuSeki Kigyo No Jinteki Shigen Kanri -Karuhu-ru No Kokusai Tenkai Wo Jirei To Shite (pp.17-29). Tokyo: Research Institute of Business Administration, Waseda University.

Shou, S. (2003). Taiwan Karuhu-ru No Genchika Purosesu. In T. Yahagi (Ed.), Chugoku • Ajia No Kourigyo Kakushin (pp. 147-175), Tokyo: Nikkei. 
Suzuki, Y. (2007). Jinteki Shigen Kanriron, Tokyo: Soseisha.

Toba, T. (2003). Karuhu-ru No Kokunai Tenkai To Kaigai Senryaku . In Y. Shiraishi, \& M. Tanaka (Ed.), Gendai Huransu No Ryutu To Shakai-Ryutu Kouzou • Toshi • Shouhi No Haikei Bunseki (pp. 59-93). Tokyo: Minerva shobo.

STORES. Top 250 Global Retailer 2008. Retrieved June 29, 2010, from, http://www.stores.org/pdf/Top\%20250\%20list\%20for\%20web.pdf

Su, X. B. (2000). Riben Yiteng Yanghuatang De Jingying Linian He Guanli Jishu Tese. China business and trade (中国商贸). 10, 78-79.

Tung, R. L. (1982). Selection and training procedures of US, European and Japanese multinationals. California Management Review, 25, 57-71.

Wang, Q., Lin, W., \& Fang, L. (2002). Zaiyue Rixi Qiye Zhongguo Yuangoong Shouru Manyidu Diaocha. Journal of Guangzhou University (Natural Science Edition), 1, (6), 91-95.

Wei, Q. (2004). Hua lian VS Yiteng yanghuatang. Franchise market magazine, 8, 28-30.

Wong, H. W. (1999). Japanese Bosses, Chinese Workers: power and control in a Hong Kong megastore, Hawai: University of Hawaii Press.

Wu Chuming, Chengdu Ito-Yokado 'Renshi Qiangzhen' Sige Dianzhang Huangdiao Le Sange, 02, Dec, 2010. Retrieved from Sichuan online: http://sichuan.scol.com.cn/cddt/content/201012/02/content_1644874.htm?node=965, accessed on 20, Jan, 2011.

Yahagi, T. (2007). Aeon No Chugoku Senryaku. In T. Yahagi (Ed.), Kouri Kokusaika Purosesu Rironto Ke-su De Kangaeru (pp. 151-182). Tokyo: Yuhikaku.

Yahagi, T. (2007). Ito-Yokado No Chugoku Senryaku. In T. Yahagi (Ed.), Kouri Kokusaika Purosesu -Rironto Ke-su De Kangaeru_(pp. 183-200). Tokyo: Yuhikaku.

Yi, H. (1997) Yiteng Yanghuatang De Dianzhang Huiyi. Think Tank of Science \& Technology, $10,39-40$.

Zhang, J. (2008). Shikan Yiteng Yanghuatang Dui Chengdu Lingshouye De Yingxiang. Science \& Technology Association Forum. 5, 123.

Zhao, Z. (2010). Yiteng Yanghuatang: Zuo Lingshou Xuyao Yanguang. The World of Enterprise, 11, 44-46.

Zhu, F. (2006). Woerma He Jialefu, Beijing: Chinese economy. 